\title{
SETTLEMENT OF TURKIC TRIBES IN AZERBAIJAN AND THE REFLECTION OF THIS PROCESS IN THE COUNTRY'S TOPONYMY
}

\author{
Ramil E. Agaev \\ Institute of History named after A.A. Bakikhanov, National Academy of Sciences of Azerbaijan, \\ Baku, Republic of Azerbaijan
}

\begin{abstract}
Studying the problems related to the process of the Azerbaijanian people formation requires a comprehensive analysis of mutual relations of the Turkic tribes - the Huns, the Sabirs and the Khazars - with the local population of Azerbaijan in the early Middle Ages. The article is devoted to the process of penetration of the Huns, the Sabirs and the Khazars to Azerbaijan, their role in the formation of the Azerbaijanian people and the reflection of this process in the country's toponymy.

In the early Middle Ages the process of penetration of Turkic tribes in Azerbaijan from the north, through the Derbent passage, intensified. Primary sources indicate that over the centuries the Huns ( $3^{\text {rd }}-4^{\text {th }}$ centuries), the Sabirs $\left(5^{\text {th }}-6^{\text {th }}\right.$ centuries) and the Khazars $\left(7^{\text {th }}-8^{\text {th }}\right.$ centuries) made continuous attacks on Azerbaijan and neighboring countries from the north. Upon the arrival of the Turkic tribes in Azerbaijan from the north in the $3^{\text {rd }}-4^{\text {th }}$ centuries, the Turkic language in the country was extensively spread. Just since then the ethnotoponyms "Hun", "Suvar" and "Khazar" became consolidated in the toponymy of Azerbaijan.

Revealing the meaning of toponyms, ethnonyms, town names, hydronyms, introduced in language use in the $3^{\text {rd }}-8^{\text {th }}$ centuries and associated with the aforementioned tribes, has exceptional value for recreating the ethnic view of Azerbaijan of the studied epoch. They let us come to the conclusion that the Huns, the Sabirs and the Khazars were important ethnic elements in the process of ethnogenesis of the Azerbaijanian people. Khazars.

Key words: Azerbaijan, antique and early medieval Albania, Balasakan, Derbent, toponym, Huns, Sabirs,

Citation. Agaev R.E. Settlement of Turkic Tribes in Azerbaijan and the Reflection of This Process in the Country's Toponymy. Vestnik Volgogradskogo gosudarstvennogo universiteta. Serija 4, Istorija. Regionovedenie. Mezhdunarodnye otnoshenija [Science Journal of Volgograd State University. History. Area Studies. International Relations], 2017, vol. 22, no. 4, pp. 46-55. (in Russian). DOI: https://doi.org/10.15688/jvolsu4.2017.4.5

\section{ПОСЕЛЕНИЕ ТЮРКСКИХ ПЛЕМЕН В АЗЕРБАЙДЖАНЕ И ОТРАЖЕНИЕ ЭТОГО ПРОЦЕССА В ТОПОНИМИКЕ СТРАНЫ}

Рамил Э. Агаев

Институт истории им. А.А. Бакиханова, НАН Азербайджана, г. Баку, Азербайджанская Республика

Аннотация. Для изучения проблем, связанных с процессом формирования азербайджанского народа, необходимо комплексное освещение взаимоотношений тюркских племен - гуннов, сабиров и хазар - с местным населением Азербайджана в эпоху раннего Средневековья. 
Статья посвящена процессу проникновения гуннов, сабиров и хазар в Азербайджан, их роли в формировании азербайджанского народа, отражению этого процесса в топонимике страны.

В эпоху раннего Средневековья усилился процесс проникновения тюркских племен в Азербайджан с севера, через Дербентский проход.

Первоисточники свидетельствуют о том, что в течение столетий гунны (III-IV вв.), сабиры (V-VI вв.) и хазары (VII-VIII вв.) совершали продолжительные нападения на Азербайджан и соседние страны. Значительная часть тюркских племен, с давних времен нападавших на Азербайджан, постепенно оседала здесь и сливалась с местным населением страны. С приходом тюркских племен в Азербайджан с севера в III-VIII вв. расширился масштаб распространения в стране тюркоязычия. Этнотопонимы «гунн», «сувар» и «хазар» именно с этого времени утвердились в топонимике страны.

Исключительное значение для воссоздания этнической картины Азербайджана изучаемой эпохи имеет выявление смысла топонимов, этнонимов, ойконимов, гидронимов, возникших в III-VIII вв. и связанных с вышеупомянутыми племенами. Они позволяют нам прийти к выводу, что гунны, сабиры и хазары были важными этническими элементами в процессе этногенеза азербайджанского народа.

Ключевые слова: Азербайджан, античная и раннесредневековая Албания, Баласакан, Дербент, топоним, гунны, сабиры, хазары.

Цитирование. Агаев Р. Э. Поселение тюркских племен в Азербайджане и отражение этого процесса в топонимике страны // Вестник Волгоградского государственного университета. Серия 4, История. Регионоведение. Международные отношения. - 2017. - Т. 22, № 4. - С. 46-55. - DOI: https://doi.org/10.15688/ jvolsu4.2017.4.5

Территория Азербайджана на протяжении столетий являлась местом поселения и слияния различных племен и народов, живших в различные периоды в Азербайджане. Они оставили свои глубокие следы в истории страны, азербайджанского народа.

Исключительное значение для воссоздания картины этногенетической эволюции азербайджанского народа имеет выявление смысла различных «-нимов» (топонимов, этнонимов, ойконимов, гидронимов и др.), возникших на территории Азербайджана в эпоху раннего средневековья. Несомненно, все эти «-нимы» создавались различными племенами, народностями и народами на протяжении длительного времени и нашли свое отражение в географических, этнографических, этнотопонимических и смешанных наименованиях.

Сравнительное изучение топонимов, особенно этнотопонимов, имеющихся на территории Азербайджана, и сведений, содержащихся в письменных первоисточниках, дает исследователю возможность решить некоторые вопросы, связанные с миграциями и поселениями, происходившими на территории страны на различных исторических этапах, выдвинуть определенные мнения, соображения по вышеупомянутым проблемам.

Среди населения, жившего на территории Азербайджана накануне арабского завоевания, особое место занимали тюркские племена - гунны, сабиры и хазары, которые вначале сражались с Сасанидами, а затем с арабами.

Одним из тюркских племен, активно участвовавших в формировании азербайджанского народа, были гунны. Без исследования вопроса о поселении гуннов на территории Азербайджана, находившемся севернее реки Араз (в Албании - Арране), невозможно фундаментальное изучение проблем, связанных с формированием азербайджанских тюрков, а также определение этнического состава населения страны в период существования Арабского халифата. Поэтому вопросы, связанные с историей гуннов, всегда были в центре особого внимания азербайджанских историков. В числе таких авторов следует отметить Ю.Р. Джафарова, издавшего еще в 1985 г. монографию «Гунны и Азербайджан» [17].

История гуннов, сабиров и хазар тесно связана также с историей ряда народов Северного Кавказа, Поволжья, Центральной Азии, Западной Европы, с историей славян. Поэтому многие историки, востоковеды, археологи, занимавшиеся изучением истории вышеуказанных современных народов, уделяли особое внимание вопросам, связанным с гуннами, сабирами и хазарами. Эти исследователи (М.И. Артамонов, В.В. Бартольд, Л.Н. Гумилев, М.Г. Магомедов, А.П. Новосельцев, С.П. Толстов, С.В. Киселев, Я.А. Федоров, Г.С. Федо- 
ров, С.А. Плетнева, А.Н. Бернштам, С.Г. Кляшторный, М. Аджи, О. Ивик, В. Ключников, В.Ф. Минорский, Г. Клаусон, Н.Ю. Мерперт, Ф. Хирт, Н. Вамбери, П.Е. Кале, Е. Томсон, А. Алфольди, Д.М. Данлоп, П. Голден, К.И. Брук, А. Кастлер, 3.В. Тоган, А. Инан, А. Джафароглу, И. Кафесоглу, Д. Авчыоглу и др.) провели археологические раскопки, издали ценные монографии и статьи. Однако вышеупомянутые авторы в основном затронули проблемы, связанные с походами гуннов, их деятельностью в Северном Кавказе и Восточной Европе. А вопросы, связанные с поселением гуннов в Азербайджане и с их ролью в становлении азербайджанского народа, остались вне поля зрения этих исследователей.

Гунны, сабиры и хазары, поселившиеся на западном побережье Каспийского моря, в Северном Кавказе, на берегах Черного моря, неоднократно проникали в Южный Кавказ через Дербентский проход. После этих походов они поселились в основном в Северном Азербайджане. Однако они во многих случаях переходили реку Араз и проникали на территории Южного Азербайджана.

Сасанидские шаханшахи в основном были не в состоянии предотвратить походы гуннов на Южный Кавказ. В период военнополитического противостояния Сасанидов и гуннов основными аренами борьбы стали Южный Кавказ и Азербайджан. Гунны и другие тюркские племена, проникшие вместе с ними в Азербайджан, на протяжении столетий оседали в стране и превратились в решающий фактор в становлении этнической карты региона. Гунны и другие тюркские племена, живщие в течение длительного времени в северной части Азербайджана, слились с местным населением, подверглись ассимиляции и получили общее название - «тюрки».

В исторической литературе утвердилось мнение о том, что «походы гуннов и других тюркских племен на Южный Кавказ сопровождались грабежами и разрушениями» $[18$, c. 57]. Однако археологические раскопки, исследования, проведенные на территории северо-восточного Азербайджана, опровергают это мнение. Здесь обнаружены остатки многих городов, крепостей, поселений сельского типа, относящихся к эпохе раннего Средневековья. Плотность населенных пунктов, посе- лений на этих территориях свидетельствует не о «грабежах и разрушениях», а об экономическом подъеме изучаемого края [18].

В письменных источниках упомянуты топонимы, непосредственно связанные с гуннами, жившими в эпоху раннего Средневековья на территории Азербайджана. Ряд топонимов Азербайджана до сих пор хранит в себе этноним «Ггунн» («хунн»).

Еще в V в. гунны имели огромные поселения на территории современного Мугана. Одним из названий области Муган в тот исторический период был «Баласакан». Самое раннее упоминание Баласакана мы находим в трилингве (среднеперсидская, парфянская и греческая версии) Шапура I (240-272 гг.) на Каабе Зороастра в археологической зоне Накше-Рустаме (составлен в 262 г.) и в надписях верховного зороастрийского жреца Картира (надписи 290-293 гг.) [9, с. 68-69; 22, c. 48]. Именно в этот период гунны заложили на юге области Муган основу города Агхун (Баласагун). Арабский историк, автор сочинения «Китаб ал-футух» («Книга завоеваний») Абу Мухаммад Ахмад Ибн Асам ал-Куфи (ум. в 926 г.) называл эту территорию «равниной Баласаджан» [3, с. 247]. Авторы раннесредневековых сочинений называют гуннов, живущих на этой территории, «тюрками». Например, византийский историк Феофилакт Симокатта отмечает, что Губад I (488-531) «пошел к гуннам», которых наши историки называют «тюрками» [11, с. 172]. Можно предполагать, что топоним «Баласакан» был связан с «баласаджылар»ами, считавшимися одним из гуннских племен.

Албанский летописец Моисей Каланкатуйский ведет речь о походах гуннов на Албанию, а затем представляет нам сведение о «царе Баласакан» [21, с. 44].

В эпоху раннего Средневековья одна из крепостей в Арране называлась «Хун галасы» («Крепость гуннов»). По мнению некоторых исследователей, грандиозные руины этой крепости сохранились до сих пор под названием «Торпаггала» («Земляная крепость») на правом берегу реки Кюр. Близлежащую территорию доныне называют «Хунан дюзю» («Хунанская равнина») [16, с. 126]. Важное сведение о городе Хунан имеется и в сочинении «История Албании» Моисея Каланкатуйского [21, с. 19]. 
Историки выдвинули различные соображения о городе Хунан и о месте расположения этого населенного пункта. Название города Хунан связано с гуннами, и никто не сомневается в этом. Л.М. Меликсет-Беков однозначно отмечал, что название «Хунан» связано со словом «хунн» («гунн») [26, с. 712]. В трудах многих арабоязычных авторов (ал-Балазури, ал-Истахри, Ибн Хаукал, ал-Мугаддаси), а также в персоязычных источниках неоднократно упомянуто название города Хунан, где он представлен в числе «городов Аррана».

Опираясь на сведения почти всех арабоязычных источников, можно прийти к нижеследующему общему выводу: город Хунан находился на пути Барда - Тифлис. Например, ал-Истахри относит Хунан к небольшим городам Аррана, находившимся на пути Тифлис - Барда. Он отмечал, что расстояние между городами Шамкир и Хунан составляет 21 фарсах [2, с. 113]. Ибн Хаукал указывал, что Хунан находился между городом Шамкир и крепостью Ибн Кендмен [19, с. 350]. Аналогичное сведение встречается и в трудах ал-Мугаддаси [5, с. 372], ал-Идриси [14, c. 150] и других арабоязычных авторов. Однако соображения, мнения, выдвинутые некоторыми исследователями (И. Маркварт, Н. Караулов, В.Ф. Минорский, Р.М. Вахидов, Н.М. Гулиев, А.М. Мамедов и др.) в связи с точным местонахождением города Хунан, несколько отличаются. Например, В.Ф. Минорский считал, что город Хунан находился в середине пути Тифлис - Гянджа [28, с. 47].

В последние годы азербайджанские археологи провели определенные археологические раскопки, исследования в области уточнения места расположения раннесредневекового города Хунан и выдвинули новые соображения по этому поводу [25].

Р.М. Вахидов и Н.М. Гулиев, опираясь на сведение арабоязычного автора ал-Истахри, который называл место расположения города Хунан «Галат ат-турабом» - «Земляной крепостью», отождествили ее с «Торпаггала», находящимся вблизи современного города Товуз. В. Багратиони считает, что раннесредневековый город Хунан находился на территории села Икинджи Шыхлы Газахского района Азербайджана. В результате разведочных археологических работ, проведенных в 2007 г. под руко- водством А.М. Мамедова, исследователи пришли к выводу, что мнения Р.М. Вахидова и Н.М. Гулиева не соответствуют действительности, «город Хунан находился на территории села Икинджи Шыхлы (как указывал В. Багратиони), на высоком земляном холме, где находится памятник “Гыз галасы” ““Девичья крепость”)» [24, с. 89]. Наряду с выводом архелогов следует упомянуть категорическое сведение ал-Истахри: «Хунан находится на высоком холме и поэтому известен как "Галат ат-тураб” (“Торпаггала")» [2, с. 111].

Можно предполагать, что топонимы «Хунабад» и «Хунашин», встречающиеся в Гарабагском регионе Азербайджана, связаны с этнонимом «хунн» («гунн»). М.Х. Шарифли называл племя «Хыналыг», доныне живущее на территории Северного Азербайджана (в селе Хыналыг Губинского района Республики), «Хунлуг» и предполагал, что основу села Хыналыг могли заложить гунны, проникшие сюда в IV веке [35, с. 34].

Одним из топонимов, связанных с гуннами, является «Хун бели» («Гуннский хребет, перевал»), который встречается ныне на территории населенного пункта Илису Гахского района Северного Азербайджана [23, с. 85]. Считаем, что топоним «Гарахун» (высокогорное пастбище), встречаемый в Шемахинском районе нашей страны, также связан с гуннами.

В результате увеличения числа гуннов в IV-VI вв. на территории между реками Араз и Кюр возникла «Страна гуннов». Грузинские летописцы отмечают, что в нескольких городах, расположенных у берегов реки Кюр, жили гуннские племена, которые называли «бунтюрками» $[11$, с. 172$]$. Византийский историк Феофан писал, что в 624 г. «царь Ираклий II и хазары встретились в Албании - в стране гуннов» $[16$, с. 126$]$.

Топонимы, связанныес этнонимом «гунн» («хунн»), нашли свое отражение также в некоторых источниках и документах, составленных в последующие периоды истории.

Отметим, что мнение «о принадлежности катакомбных захоронений, обнаруженных в Мингечауре [на территории Северного Азербайджана], только аланам» уже вызывает сомнения. Например, И.М. Мизиев пришел к выводу, что «эти катакомбные захоронения могли принадлежать гуннам» [27, с. 144]. Из- 
вестно, что катакомбные захоронения были распространены и в Центральной Азии, они имеют своеобразные, локальные особенности [34, с. 99-100]. Предположение о связи этих катакомбных захоронений с гуннами уже было выдвинуто в научной литературе [10, с. $102-$ 103]. Однако Я.А. Федоров и Г.С. Федоров отмечали, что некоторые исследователи решительно отвергают предположение о принадлежности катакомбных захоронений гуннам [33, c. 28].

Тюркское племя сабиров (субаров, суваров, савиров) упомянуто в ряде раннесредневековых источников. Вопрос о происхождении сабиров очень сложный. В научной литературе имеется мнение о том, что сабиры, как и хазары, были предками чувашей [31].

Наряду с арабоязычными источниками, сведения о сабирах имеются в византийских, армяноязычных, сирийских, еврейских (иудейских) источниках, и эти сведения мало отличаются друг от друга. Византийский автор Феофилакт Симокатта считал сабиров вместе с оногурами «одним из гуннских племен» [32, с. 160]. Историки VI в. Прокопий Кесарийский и Агафий называют гуннов, живших в Северном Кавказе, сабирами [30, с. 41]. Некоторые историки и раннесредневековые авторы связывают сабиров с хазарами. Случаи отождествления сабиров с хазарами встречаются также в сочинениях арабоязычных авторов. Например, об этом свидетельствуют нижеследующие слова ал-Масуди: "و الخزر، ويدعون بالتركية سبير و بالفارسية خزار ان و هم جنس من الثزكي"

Перевод: «Хазары на тюркском языке называют их "сабир", а на персидском - хазаран. Они относятся к тюркскому роду» $[4$, с. 83$]$.

Сабиры были основными участниками военно-политических событий, произошедших в 50-х гг. VI столетия [6, с. 71-74]. Албанский хронист Моисей Каланкатуйский, армяноязычные и арабоязычные авторы порой называли этих сабиров «хазарами». Моисей Каланкатуйский отмечал, что в тот период переход хазар (сабиров) через Дербентский проход усилился до такой степени, что Албанская церковь была вынуждена перенести свою резиденцию из Чолы (Дербента) в Партав (Барду) $[21$, с. 83]. Именно тогда сабиры захватили всю северную часть Албании и перешли к оседлому образу жизни. В 60-х гг. VI в. сабиры потерпели на Северном Кавказе очередное поражение от аваров, и новые отряды этого племени переселились в Албанию. Таким образом, число сабиров в Албании резко увеличилось [16, с. 128].

Г.А. Гейбуллаев отмечал, что по сведениям византийского историка VI в. Менандра Сасанидский шаханшах Хосров Ануширеван I (531-579) разгромил сабиров и переселил 10 тысяч из них на территорию между реками Араз и Кюр [16, с. 128]. И в других источниках имеется сведение о том, что в указанный период на северных территориях Азербайджана поселилось огромное число сабиров-гуннов [11, с. 172].

Часть сабиров, оставшихся в Северном Кавказе, сначала попала в зависимое положение от булгаров, а затем вместе с булгарами от хазар и ассимилировалась среди них. А часть суваров (сабиров) отошла к Поволжью.

Можно предположить, что название города Сувар в Поволжье связано с суварами. Отметим, что Ибн Хаукал и ал-Истахри в своих сочинениях представляют нам сведения о городе Сувар (سوار), находившемся на берегу реки Итиль (Волга), вблизи города Булгар [2, с. 132; 19, с. 396]. Название города-крепости Сувар упомянуто и другими авторами, в том числе Ибн Хордадбехом [20, c. 109]. Здесь уместно указать, что некоторые исследователи (А.П. Ковалевский, В.Ф. Каховский, Н.М. Велиханлы) считают слово «чуваш» видоизмененной формой слова «сувар» [20, с. 307].

Таким образом, сабиры играли центральную, ведущую роль в военно-политических событиях, произошедших в основном в VVI вв. в Азербайджане. Уже в VI в. племена сабиров (савиров, суваров) создали на территории Габалы многочисленные населенные пункты. Часть этих племен поселилась в Гянджабасаре (Шакашене), на территории между Акстафой и Шамкиром [15, с. 64].

Результатами всех этих движений, миграций, поселений, произошедших в эпоху раннего Средневековья, являются этнотопонимы, связанные с этнонимом «сувар». Сохранившиеся до сих пор названия ряда местностей Азербайджана свидетельствуют о том, что именно там в прошлом существовали поселения сабиров (суваров, савиров). 
Топоним «Биласувар» (в Муганской степи) упоминается во многих сочинениях всего Средневековья. Персоязычный автор XIV в. Хамдуллах Газвини ведет речь о населенном пункте «Тутсувар», находившемся в Южном Азербайджане. Эти топонимы связаны с сабирами. С.Б. Ашурбейли считала, что компонент «била-», входящий в состав слова «Биласувар», имеет значение «место», «город» $[9$, c. 76]. Можно также предполагать, что арабы назвали эту территорию «Баладу Сувар» («Страна Суваров») позже. Несомненно, очень трудно высказать конкретное, категорическое мнение об истинном значении, о происхождении слова «Биласувар».

В северо-восточном Азербайджане (в Губинском районе) в XIX в. сохранились остатки крепости «Галейсувар» («Крепость суваров») $[16$, c. 128$]$. В одном архивном документе на территории бывшего Губинского ханства зарегистрированы «кишлак» (от тюркского слова «Гышлаг», место для зимовки), «Галейсувар» и село «Суварлы» [16, с. 129]. Руины крепости в селе Рустов Губинского района Азербайджанской Республики до сих пор называются «Галейе Суарун» («Крепость суваров»).

В научной литературе имеется мнение о том, что название города Шабран (в Азербайджанской Республике) связано с сабирами [29, с. 68-69]. Предполагаем, что топонимы «Сувар», «Сабироба», встречающиеся в Хачмазском районе Азербайджанской Республики, связаны именно с сабирами.

Перечисленные этнотопонимы не оставляют сомнений относительно их тюркского происхождения (от этнической общности, племени «Сувар») и позволяют нам прийти к выводу о том, что сабиры (сувары) в эпоху раннего Средневековья были одним из этнических компонентов, сыгравших важную роль в процессе формирования азербайджанского народа.

Не прошло и ста лет после прихода суваров на территорию Азербайджана (VVII вв.), как на северных склонах Кавказских гор власть перешла в руки хазар. В связи с этим в 30-40-х гг. VII столетия начался новый наплыв тюркских племен и народностей из Северного Кавказа в Северный Азербайджан. Это обстоятельство привело к значительному увеличению числа тюркских племен и народностей, осевших на исторических территориях Азербайджана.

VII век можно считать кульминацией в процессе проникновения хазаро-тюркских племен в античную Албанию и поселения их на территории страны, где появились новые, большие населенные пункты тюрков. События этого исторического периода нашли свое отражение во второй книге «Истории Албании» Моисея Каланкатуйского [21, с. 99-107]. Сведения, представленные в этом сочинении и в других источниках, свидетельствуют о том, что уже с 20-х гг. VII столетия Северный Азербайджан был под властью тюрков-хазар и в 628-629 гг. албаны считали свою страну «вечным владением Хазарского хагана» [11, с. 53]. Не случайно, что сын хазарского правителя Чебу хагана - Шад, обращаясь к католикосу Албании Виро, говорил: «За каждое мое вторжение в твою страну я расплачусь с тобой пленными и скотом вдвое, ибо мой отец завоевал эти три страны - Албанию, Лпинк и Чолу навечно» [21, с. 118]. С этой точки зрения интересен также ответ католикоса Албании Виро: «Мы и все жители этой страны являемся подданными твоего отца и твоими подданными» [21, с. 118].

В 682 г. албанский князь Вараз Трдат заявил всем албанам: «Мы уже не в состоянии предотвратить наплыв хазар в Албанию, поэтому отправим к ним своих послов для ведения переговоров, не следует страшиться их и относиться к ним враждебно» [21, с. 164]. В договоре, заключенном в 685 г. арабским халифом и византийским императором Юстинианом II, говорится о том, что «население Аррана [Албании] платит налоги хазарам» [11, c. 103]. Этот факт нашел свое отражение и в сочинении «История Албании» Моисея Каланкатуйского [21, с. 198].

В зените своего могущества (VIIVIII вв.) хазары подчинили своей власти отдельные народы и племена, находившиеся на различных ступенях развития. В этот период они полностью подчинили или же поставили в зависимое от себя положение (получая дань от вассалов) почти 30 племен и народов. Хазарский хаганат можно оценить как «военную конфедерацию», возглавляемую хазарами. В этой «конфедерации» наряду с хазарами значительную роль играли булгары, бур- 
тасы, гузы и даже мадьяры (предки современных венгров). Однако в первоисточниках все они упоминаются под общим названием «хазары». Эти племена, часто проникавшие в территорию Азербайджана в составе хазар, надолго остались, поселились на севере страны, слились с местным населением, подверглись ассимиляции и получили общее название «тюрки». Хазары, поселившиеся в стране, сыграли определенную роль в формировании азербайджанского тюркского народа и в становлении некоторых диалектов азербайджанского тюркского языка.

Вопрос о длительности пребывания хазар в Азербайджане до сих пор остается не решенным. В исторической науке долго преобладало мнение, выдвинутое М.В. Артамоновым, который считал, что хазары господствовали на Южном Кавказе три года. А.Е. Крымский называл период в течение почти ста лет, при этом Габала был их административным центром. 3.М. Буниятов, касаясь этого вопроса, отмечал, что мнение А.Е. Крымского более соответствует исторической действительности [11, с. 54-55; 12 , c. 21-25]. Ф.М. Асадов, рассматривая, анализируя высказанные мысли различных исследователей, выразил свое мнение об этой дискуссии, выдвинул интересные соображения. Он считает, что до второй половины VIII в. хазары оставались основным, ведущим фактором в Албании [7, с. 16].

Хазары на протяжении долгого времени жили на территории Северного Азербайджана, занимали главное место в массе тюркских племен и народов. Именно поэтому арабы иногда называли Северный Азербайджан «Страной Хазар». Например, ат-Табари, говоря о сипахбудстве «Азербайджан», называет его «Страной Хазар» (هي بلاد الخزر) [8, с. 92].

Ал-Балазури, говоря о Северном Азербайджане, иногда называет эту территорию «Страной хазар». Он даже представляет арранский (албанский) город Габала «Хазар»:

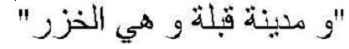

Перевод: «Город Габала тот же город Хазар» [1, с. 232].

Как видно из всего вышеизложенного, история хазар тесно связана с историей азербайджанского народа. Об этом свидетельствуют также материалы по топонимике Азербайджана.
В прошлом в Габале и на территории соседних областей были села под названием «Хазары» [11, с. 55]. Топонимы «Хазардаг» («Гора Хазар»), «Хазарюрд» («Местожительство Хазар»), «Хазаряйлаг» («Яйлаг Хазар»), «Хазарсянгар» («Хазарский окоп»), «Хазартепе» («Хазарский холм») на территории Азербайджана хранят в себе этноним «Хазар».

С одним из походов хазар на Южный Кавказ связан уникальный памятник, исследованный А.А. Иессеном в Азербайджане. Это впускное погребение одного из больших курганов «Учтепе» («Три холма»). Сложная конструкция погребального сооружения, потребовавшая усилий большого числа людей, богатый инвентарь памятника привели А.А. Иессена к заключению, что в кургане «Учтепе» был погребен хазарский вождь. Инвентарь погребения позволяет датировать его концом VI - началом VII века [33, с. 64-65]. Правда, тогда источники упоминают хазар в качестве «союзников тюркютов». Однако, несмотря на это сведение, данный погребальный памятник ярко свидетельствует о том, что хазары оставались на территории Азербайджана еще долгое время.

Часть хазар в результате длительних войн с арабами, ослабевания и падения Хазарского хаганата отошла на север - к Поволжью. В результате хазары слились с азербайджанскими тюрками, с народами Северного Кавказа и Поволжья, подверглись ассимиляции и как отдельный, независимый народ покинули историческую сцену.

Таким образом, в результате проведенного исследования можно прийти к заключению, что с приходом новых тюркских племен в Азербайджан с севера в III-VIII вв. расширился масштаб распространения в стране тюркоязычия. Об этом свидетельствуют многие топонимы, связанные с этими племенами, народами. Этнотопонимы «гунн», «сувар» и «хазар» именно с этого времени утвердились в топонимике Азербайджана.

Исключительное значение для воссоздания этнической картины Азербайджана изучаемой эпохи имеет выявление смысла этих топонимов, возникших в III-VIII вв. и связанных с вышеупомянутыми племенами. Они позволяют нам заключить, что гунны, сабиры и хазары были важными этническими элементами в процессе этногенеза азербайджанского народа. 


\section{СПИСОК ЛИТЕРАТУРЫ}

1. Ал-Балазури, Абу-л-Аббас Ахмад Ибн Йахйа Ибн Джабир ал-Балазури. Китаб футух албулдан (Книга завоевания стран) / Ал-Балазури. Бейрут : Дар ал-китаб ал-илмиях, 2000. - 286 с.

2. Ал-Истахри. Китаб масалик ал-мамалик (Книга путей государств) / Ал-Истахри. - Каир : Дар ал-галм,1961.-215 с.

3. Ал-Куфи. Китаб ал-футух (Книга завоеваний). T. VII-VIII / Ал-Куфи. - Бейрут : Дар ал-адва, 1991. $-453 \mathrm{c}$.

4. Ал-Масуди. Китаб ат-танбих ва-л-ишраф (Книга предупреждения и пересмотра) / Ал-Масуди. - Лейден : Брилл, 1894. - 552 с.

5. Ал-Мукаддаси. Ахсан ат-таксим фи марифат ал-акалим (Наилучшее разделение для познания климатов) / Ал-Масуди. - Лейден : Брилл, 1967. $498 \mathrm{c}$.

6. Артамонов, М. И. История Хазар/ М. И. Артамонов. - Ленинград : Изд-во Гос. Эрмитажа, 1962. $-501 \mathrm{c}$.

7. Асадов, Ф. М. Полемика о длительности доминирования хазар на Южном Кавказе в хазароведческих исследованиях второй половины ХХ века / Ф. М. Асадов // Средневековый Восток: проблемы историографии и источниковедения : (Сб. ст. памяти Героя Советского Союза, акад. 3.М. Буниятова). - Баку : Элм, 2015. - С. 16-35.

8. Ат-Табари. Тарих ар-русул ва-л-умам. (История пророков и наций). Т. II / Ат-Табари. - Каир : Хусейнийа, 1960. - 300 с.

9. Ашурбейли, С. Б. Государство Ширваншахов (VI - XVI вв.) / С. Б. Ашурбейли. - Баку : Аврасия пресс, 2006. -416 с.

10. Бернштам, А. Н. Очерк истории гуннов /А. Н. Бернштам. - Ленинград : Изд-во ЛГУ, 1951. $255 \mathrm{c}$.

11. Буниятов, 3. М. Азербайджан в VII-IX вв / З. М. Буниятов. - Баку : Элм, 1989. - 336 с. (на азерб. яз.).

12. Буниятов, 3. М. О длительности пребывания хазар в Албании в VII-VIII вв. / 3. М. Буниятов // Известия АН АзССР. Серия общественных наук. Баку: Элм, 1961. - № 1. - С. 21-34.

13. Валиди, А. 3. Историческая география Азербайджана /А. 3. Валиди : пер. с тур., авт. предисл., коммент., замеч. и указ. В. З. Пириева. - Баку : Техсил, 2009. - 112 с. (на азерб. яз.).

14. Велиханлы, Н. М. Арабские географы-путешественники X-XI вв. об Азербайджане / Н. М. Велиханлы. - Баку : Элм, 1974. - 220 с. (на азерб. яз.).

15. Велиханлы, Н. М. Арабский Халифат и Азербайджан / Н. М. Велиханлы. - Баку : Азернешр, 1993. - 157 с. (на азерб. яз.).
16. Гейбуллаев, Г. А. К этногенезу азербайджанцев / Г. А. Гейбуллаев. - Баку : Элм, 1991. - 552 с.

17. Джафаров, Ю. Р. Гунны и Азербайджан / Ю. Р. Джафаров - Баку : Элм, 1985. - 124 с.

18. Достиев, Т. М. Этнокультурные процессы в северо-восточной Албании в раннем средневековье / Т. М. Достиев // Вестник Бакинского университета. Серия гуманитарных наук. - 2013. - № 2. - С. 56-62.

19. Ибн Хаукал. Китаб сурат ал-ард (Книга изображения земли). Т. 2 / Ибн Хаукал. - Лейден : Брилл, 1939. $-528 \mathrm{c}$.

20. Ибн Хордадбех. Книга путей и стран / Ибн Хордадбех : пер. с араб., коммент., исслед., указ. и карты Н. М. Велихановой. - Баку : Элм, 1986. - 428 с.

21. Каланкатуйский, М. История Албании. Мхитар Гош. Албанская хроника / М. Каланкатуйский ; предисл., пер., замеч. и коммент. 3. М. Буниятова. - 2 изд. - Баку : Аврасия Пресс, 2006. -296 с.

22. Касумова, С. Ю. Азербайджан в III-VII вв.

/ С. Ю. Касумова. - Баку : Элм, 1993. - 140 с.

23. Летифова, Э. М. Илисуйское султанство / Э. М. Летифова. - Баку : Шарг-Гарб, 2010. - 400 с.

24. Мамедов, А. М. Древняя Гянджа / А. М. Мамедов. - Баку : Текнур, 2014. - 176 с.

25. Мамедов, А. М. Новый взгляд на историю города Хунан / А. М. Мамедов, Э. С. Аббасова // Археологические и этнографические исследования в Газахском регионе : сб. ст. / сост. и авт. предисл. А. М. Мамедов, Э. С. Аббасова. - Гянджа : Элм, 2008. - С. 178-185. (на азерб. яз.).

26. Меликсет-Беков, Л. М. К истории появления гуннов в Восточном Закавказье / Л. М. Меликсет-Беков // ДАН Азерб. ССР. - 1957. - Т. XIII, № 6. С. 709-713.

27. Мизиев, И. М. Шаги к истокам этнической истории Центрального Кавказа / И. М. Мизиев. Нальчик : Эльбрус, 1986. - 184 с.

28. Минорский, В. Ф. История Ширвана и Дербента X-XI веков / В. Ф. Минорский. - М. : Изд-во вост. лит., 1963. -265 с.

29. Мирзазаде, Ч. Х. Топонимы Азербайджана в средневековых арабских географических источниках / Ч. Х. Мирзазаде. - Баку : Элм, 1988. $119 \mathrm{c}$.

30. Пигулевская, Н. В. Сирийские источники по истории народов СССР / Н. В. Пигулевская. - М. ; Л. : Наука, 1941. - 172 с.

31. Салмин, А. К. Краткая история савиров / А. К. Салмин // Вестник Томского государственного университета. - 2014. - № 382. - С. 119-125.

32. Симокатта Феофилакт. История / Симокатта Феофилакт ; пер. С. П. Кондратьева. - М. : Наука, 1957. $-224 \mathrm{c}$.

33. Федоров, Я. А. Ранние тюрки на Северном Кавказе / Я. А. Федорова, Г. С. Федорова. - М. : МГУ, 1978. - $296 \mathrm{c}$. 
34. Халилов, Дж. А. Материальная культура Кавказской Албании (IV в. до н.э. - III в. н. э.) / Дж. А. Халилов. - Баку : Элм, 1985.-279 с.

35. Шарифли, М. Х. Феодальные государства Азербайджана во второй половине IX - XI в. / М. Х. Шарифли. - Баку : Элм, 1978. - 343 с. (на азерб. яз.).

\section{REFERENCES}

1. Al-Balazuri, Abu-l-Abbas Akhmad ibn Yakhya ibn Dzhabir al-Balazuri. Book of Conquering Countries. Beirut, Dar al-kitab al-ilmiyakh, 2000.286 p. (in Arabic).

2. Al-Istakhri. The Book of Ways and States. Cairo, Dar al-Galam, 1961.215 p. (in Arabic).

3. Al-Kufi. Book of Conquest. Parts 7-8. Beirut, Dar al Adwan, 1991. 453 p. (in Arabic).

4. Al-Masudi. Book of Prevention and Review. Leiden, Brill, 1894. 552 p. (in Arabic).

5. Al-Mukaddasi. Best Separation for the Knowledge of Climates. Leiden, Brill, 1967. 498 p. (in Arabic).

6. Artamonov M.I. Istoriya Khazar [History of the Khazars]. Leningrad, Izd-vo Gosudarstvennogo Ermitazha, 1962.501 p.

7. Asadov F.M. Polemika o dlitelnosti dominirovaniya khazar na Yuzhnom Kavkaze v khazarovedcheskikh issledovaniyakh vtoroy poloviny XX veka [The Disputes about the Duration of the Khazar Dominance in the South Caucasus in Khazar Studies of the Second Half of the $20^{\text {th }}$ Century]. Srednevekovyy Vostok: problemy istoriografii $i$ istochnikovedeniya: (Sb. st. pamyati Geroya Sovetskogo Soyuza, akad. Z.M. Buniyatova) [Medieval East: Problems of Historiography and Source Studies: (Collection of Articles in Memory of Hero of the Soviet Union, Academician Z.M. Buniyatov)]. Baku, Elm Publ., 2015, pp. 16-35.

8. At-Tabari. History of Prophets and Nations. Part. 2. Cairo, Khuseyniya Publ., 1960.300 p. (in Arabic).

9. Ashurbeyli S.B. Gosudarstvo Shirvanshakhov $(V I-X V I v v$. $)$ [The State of Shirvanshahs $\left(6^{\text {th }}\right.$ $16^{\text {th }}$ Centuries)]. Baku, Avrasiya Press, 2006. 416 p.

10. Bernshtam A.N. Ocherk istorii gunnov [Essay on the History of the Huns]. Leningrad, Izd-vo LGU, $1951.255 \mathrm{p}$.

11. Buniyatov Z.M. Azerbaijan in the $7^{\text {th }}$ $9^{\text {th }}$ Centuries. Baku, Elm Publ., 1989. 336 p. (in Azerbaijanian).

12. Buniyatov Z.M. O dlitelnosti prebyvaniya khazar v Albanii v VII-VIII vv. [On the Duration of the Khazars' Stay in Albania in the $7^{\text {th }}-8^{\text {th }}$ Centuries]. Izvestiya AN AzSSR. Seriya obshchestvennykh nauk. Baku, Elm Publ., 1961, no. 1, pp. 21-34.
13. Validi A.Z. Historical Geography of Azerbaijan. Baku, Tekhsil Publ., 2009. 112 p. (in Azerbaijanian).

14. Velikhanly N.M. Arab Geographers-travelers of the $10^{\text {th }}-11^{\text {th }}$ Centuries about Azerbaijan. Baku, Elm Publ., 1974. 220 p. (in Azerbaijanian).

15. Velikhanly N.M. Arab Caliphate and Azerbaijan. Baku, Azerneshr Publ., 1993. 157 p. (in Azerbaijanian).

16. Geybullayev G.A. $K$ etnogenezu azerbaydzhantsev [On the Ethnogenesis of Azerbaijanians]. Baku, Elm Publ., 1991. 552 p.

17. Dzhafarov Yu.R. Gunny i Azerbaydzhan [Huns and Azerbaijan]. Baku, Elm Publ., 1985. 124 p.

18. Dostiev T.M. Etnokulturnyye protsessy v severo-vostochnoy Albanii v rannem srednevekovye [Ethno-Cultural Processes in the North-East of Albania in the Early Middle Ages]. Vestnik Bakinskogo universiteta. Seriya gumanitarnykh nauk [News of Baku University. Humanities], 2013, no. 2, pp. 56-62.

19. Ibn Khaukal. The Description of the Earth. Part 2. Leiden, Brill, 1939. 528 p. (in Arabic).

20. Ibn Khordadbekh. Kniga putey $i$ stran [The Book of Ways and States]. Baku, Elm Publ., 1986. 428 p.

21. Kalankatuyski Moisey. Istoriya Albanii. Mkhitar Gosh. Albanskaya khronika [Albanian Chronicle. Mkhitar Gosh. Albanian Chronicle]. Baku, Avrasiya Press, 2006. 296 p.

22. Kasumova S.Yu. Azerbaydzhan v III-VII vv. [Azerbaijan in the $3^{\text {rd }}-7^{\text {th }}$ Centuries]. Baku, Elm Publ., 1993. $140 \mathrm{p}$.

23. Letifova E.M. Ilisuyskoye sultanstvo [Ilisu Sultanate]. Baku, Sharg-Garb Publ., 2010. 400 p.

24. Mamedov A.M. Drevnyaya Gyandzha [Ancient Ganja]. Baku, Teknur Publ., 2014. 176 p.

25. Mamedov A.M., Abbasova E.S. A New Look at the History of the City of Hunan. Archaeological and Ethnographic Research in the Gazakh Region (Collection of Articles). Ganja, Elm Publ., 2008, pp.178185. (in Azerbaijanian).

26. Melikset-Bekov L.M. K istorii poyavleniya gunnov v Vostochnom Zakavkazye [On the History of the Appearance of the Huns in the Eastern Caucasus Redion]. DANAzerb. SSR., 1957, vol. XIII, no. 6, pp. 709-713.

27. Miziev I.M. Shagi $k$ istokam etnicheskoy istorii Tsentralnogo [Steps to Sources of an Ethnic History of Central Caucasus]. Nalchik, Elbrus Publ., 1986. $184 \mathrm{p}$.

28. Minorskiy V.F. Istoriya Shirvana i Derbenta $X-X I$ vekov [History of Shirvan and Derbent of the $10^{\text {th }}-11^{\text {th }}$ Centuries]. Moscow, Izd-vo vost. lit., 1963. $265 \mathrm{p}$.

29. Mirzazade C.K. Toponimy Azerbaydzhana v srednevekovykh arabskikh geograficheskikh istochnikakh [Toponyms of Azerbaijan in Medieval Arabic Geographical Sources]. Baku, Elm Publ., 1988.119 p. 
P.Э. Агаев. Поселение тюркских племен в Азербайджане и отражение этого процесса в топонимике страны

30. Pigulevskaya N.V. Siriyskiye istochniki po istorii narodov SSSR [Syrian Sources on the History of the USSR Peoples]. Moscow; Leningrad, Nauka Publ., 1941. 172 p.

31. Salmin A.K. Kratkaya istoriya savirov [A Brief History of Savirs]. Vestnik Tomskogo gosudarstvennogo universiteta [Bulletin of the Tomsk State University], 2014, no. 382, pp. 119-125.

32. Simokatta Feofilakt. Istoriya [History]. Moscow, Nauka Publ., 1957. 224 p.
33. Fedorov Yu. A., Fedorov G. S. Rannie tyurki na Severnom Kavkaze [Early Turks in the North Caucasus]. Moscow, MGU Publ., 1978. 296 p.

34. Khalilov Dzh.A. Materialnaya kultura Kavkazskoy Albanii (IV v. do n.e. - III v. n. e.) [The Material Culture of Caucasian Albania ( $4^{\text {th }}$ Century BC $-3^{\text {rd }}$ Century AD)]. Baku, Elm Publ., 1985.279 p.

35. Sharifli M.K. Feudal States of Azerbaijan in the Second Half of the $9^{\text {th }}-11^{\text {th }}$ Centuries. Baku, Elm Publ., 1978. 343 p. (in Azerbaijanian).

\section{Information about the Author}

Ramil E. Agaev, Doctor of Philosophy on History, Leading Researcher, Institute of History named after by A.A. Bakikhanov, National Academy of Sciences of Azerbaijan, G. Dzhavid St., 115, 1143 Baku, Republic of Azerbaijan, Ramilmahir@gmail.com, http://orcid.org/0000-0003-4721-1852

\section{Информация об авторе}

Рамил Э. Агаев, доктор философии по истории, ведущий научный сотрудник Института истории им. А.А. Бакиханова, НАН Азербайджана, ул. Г. Джавид, 115, 1143 г. Баку, Азербайджанская Республика, Ramilmahir@gmail.com, http:/orcid.org/0000-0003-4721-1852 